\title{
Nigeria: \\ Climate War. Migratory Adaptation and Farmer-Herder Conflicts
}

\author{
Temitope Edward AKINYEMI \\ Azeez OLANIYAN
}

\begin{abstract}
Climate change and its impacts on the physical environment have received increased attention in recent years, spurring debates on its global and local dimensions. While a common ground has been reached on its causes, manifestations and options for mitigation, its human security implications remain poorly understood. Links between climate change and social conflict is one of the most controversial issues in the climate change impacts assessment literature as priorities diverge between generalised scientific validity (pedagogy) and context-based security analysis (policy). This paper examines climate change-conflict linkages drawing upon experiences of migrant pastoralists and arable farming host communities in Nigeria. It found a strong causal linkage between exposure to impacts of climate change and growing incidence of conflict over renewable natural resources. It recommends contextualised analyses of the linkage as well as the integration

Temitope Edward AKINYEMI

Department of Political Science

Faculty of the Social Sciences,

of climate-related conflict into Nigeria's security policy frameworks particularly, its climate change impact assessment and intervention strategies.
\end{abstract}

Ekiti State University, Nigeria

E-mail: te.akinyemi@ymail.com

\section{Azeez OLANIYAN}

Department of Political Science, Assistant Director, Institute of Peace, Security and Governance

Ekiti State University, Nigeria

Conflict Studies Quarterly

Issue 21, October 2017, pp. 3-21

DOI:10.24193/csq.21.1

Published First Online: 10/03/2017
Keywords: Climate change, conflict, host communities, migratory adaptation, renewable natural resources.

\section{Introduction}

Despite a sizeable body of literature on its diverse ramifications, climate change remains one of the most controversial issues in recent security discourse (Adano, Dietz, Witsenburg, \& Zaal, 2012). While there have been major scientific breakthroughs in attempts to understand the nature, scope and implications of the phenomenon (IPCC, 
2007; Rose, 2010; Scientific American, 2008; Stern, 2007; Tompkins \& Adger, 2004), many areas remain opaque to analysts. The implication of climate change for social and political systems, in particular, has been the subject of major debate over the years, confounded by a complex weave of diverse socio-political, economic and physico-ecological variables (Coetzee, 2012; Conley \& Werz, 2012; Ide, 2015). Nonetheless, recent studies indicate an agreement among scholars that the phenomenon is not only real, but that it also portends serious threats to security with significant effects on social and political systems (Barnett \& Adger, 2007; Conley, 2011; Stern, 2007). It also noted that associated impacts will vary in form and scale across different regions of the world, while poor regions are most likely to face its greatest security threats (Gleditsch, 2011; Joiner, Kennedo, \& Sampson, 2012; Leary \& Kulkarni, 2007; Liverman \& Merideth, 2002).

The debate on the possible contribution of climate change to conflict is foremost among controversies generated by ongoing explorations of the social dimensions to its impacts (see Bauhaug, Gleditsch, \& Theisen, 2008; Mearns \& Norton, 2010; Raleigh, Jordan, \& Salehyan, 2008). Scholars examining the climate change conflict discourse have looked at it from diverse angles. These range from a micro level analysis focusing on individual psychosocial behaviour (Anderson, Anderson, Dorr, DeNeve, \& Flanagan, 2000; Anderson \& De-Lisi, 2011), to intra-state conflicts (Abbass, 2011; Adano et al, 2012; Adekunle \& Adisa, 2010; Buseth, 2009; Koubi, Spilker, Bo“ hmelt, \& Bernauer, 2014), and macro level analysis of inter-state conflicts (Bauhaug, 2010; Gartzke, 2011; Tir \& Diehl, 1998).

An apparent dividing line in this debate pertains to motivating priorities under-guarding analyses among authors. This divide tends to split the discourse into two narratives, namely: security-driven i.e context-based, policy-oriented understanding of the climate change-conflict nexus, on one hand (Amobi \& Onyisi, 2015; Black, Kniveton Skeldon, Coppard, Murata, \& Schmidt-Verkerk, 2008; Downing \& Patwardhan, 2003) and, on the other hand, pedagogy-oriented analysis which is aimed at building a universal explanatory theory on climate change-conflict linkage (Baechler, 1999; Kelly, \& Adger, 2000; Cook, Tang, \& Seidman, 2014).

These contentious priorities have evolved into three standpoints in the climate changeconflict nexus, namely: rebuttal, affirmation and complex causal association which underlies recent calls for contextualised analysis of the connection (Ide, 2015; Stojanov et al. 2014; Wolf, 2011). This study attempts an empirical examination of the climate change-conflict nexus by examining long-term climatic precipitations in the incessant conflicts between migrant Fulani herders and their arable farming host communities in Nigeria. The study draws on field study and key informant interviews conducted among the two groups across Nigeria's two geo-ecological zones - the North and the South.

The paper is divided into two parts: The first lays the theoretical groundwork, and draws a linkage between climate change and migratory adaptation. The second examines climate change vulnerability associated with agricultural practices, the dynamics 
of migratory adaptation and migrant versus host community conflicts, with evidence from data generated through fieldwork.

\section{Framing the Problem: A Relative Deprivation (RD) Approach}

Relative Deprivation theory has proven to be highly useful in the analysis of social movements, rebellion and violence at individual, group and system levels (Guimond \& Dube-Simard, 1983). Originating, according to Flynn (2011), in the work of sociologist Samuel A. Stouffer (1900-1960), it was first used in a study of soldiers in America after World War II, to describe how soldiers measured their personal successes by comparing standards attained in their operation units against those of other units in the military operation as opposed to broader standards in the armed forces in general. ${ }^{1}$ As an approach to understanding broader social behaviour, however, it is often associated with Ted Gurr in his book Why Men Rebel (1970) in which he looked towards psychology in his attempt at understanding the contexts in which the occurrence of aggressive behaviour takes place (Gurr, 1968, 1970). Oberschall (1978) sums Gurr's Relative Deprivation theory thus:

[T] he basic precondition of civil strife, and that the greater the deprivation, the greater the magnitude of strife. Relative deprivation in turn is produced by a discrepancy between what people think they are entitled to and what they are actually getting. As deprivation increases, frustration and anger will ensue. These psychological states will produce aggression. At the level of aggregates, many aggressive acts and tendencies will produce civil strife (p. 299).

Relative Deprivation provides a theoretical loop from which vulnerability of individuals, groups and communities to environmental stress can be linked to the emergence of grievance-based actions against another group or target (Flynn, 2011). ${ }^{2}$ According to Guimond \& Dube-Simard (1983), the core argument of the relative deprivation theory is that "people protest and rebel against their condition not when they are deprived in an absolute sense but when they "feel" deprived relative to some other [objects of] comparison, persons or groups" (p. 526).

In understanding relative deprivation as a framework for understanding climate changeconflict linkages, one may situate the circumstances of pastoral farmers vis a vis their hosts in terms of access to, or struggle for resources as two comparative value positions in which one group seeks to out-gain the other as a result of scarcity (Olaniyan,

1 Davis (1959) notes that original conceptualization of RD occurred in The American Soldier (3) volumes although the theory was never codified in the book described as 'informal'.

2 According to Flynn, "Social movement theory, which began in the late 19th century, refers to the study of social mobilization including its social, cultural, and political manifestations and consequences." 
Francis, \& Okeke-Uzodike, 2015). Highlighting the complexity of the social systems within which such contestations occur, however, Oberschall (1978) have warned that the transition from feelings of discontent and the occurrence of strife is mediated by a number of intervening factors which may either facilitate overt conflict or inhibit it.

\section{Climate Change and Ecological Systems}

Much of the arguments concerning the links between climate change and conflict targets the developing regions especially in Africa and Asia, and focuses largely on its effect on renewable natural resources (Baechler, 1998; Buseth, 2009; Homer-Dixon \& Blitt, 1998; Ide, 2015; Koubi, et al. 2014; Ngigi, 2009). Scholars argue that where a vast number of the population are poor and depend on natural resources for their survival, climate-related reductions in the supply of critical livelihood-supporting resources could trigger conflict (Barnett, 2003; Gleditsch \& Urdal, 2002; Wolt, 2011). That goes to say that the vulnerability of people's livelihood due to ecological degradation which affects critical natural resources scarcity is an important loop to conflict. This is more so in Africa where the struggle for access and control of resources is critical to understanding conflicts (Gleditsch \& Urdal, 2002).

Transition from exposure to the geophysical consequences of climate change to the incidence of conflict, especially in arid regions, is aided by such impacts as environmental degradation and desertification which comes with its corollary scarcity of essential resources particularly water and forage. Scarcity is defined by Bauhaug, Gleditsch \& Theisen (2008, p. 7) as "a low per capita availability of a renewable resource, such as freshwater" which results from either, or both of two processes, namely: (1) "a dwindling resource base, and (2) increased demand for the resource through increased population pressure and/or increased consumption". Percival \& Homer-Dixon (1998) argue that the relationship between environmental scarcity and violent conflicts lie in determining factors that are context-specific, and often include the "quantity and vulnerability of environmental resources, the balance of political power, the nature of the state, patterns of social interaction, and the structure of economic relations among social groups" (p. 280). All of these, according to them, influence how resources are used, the effects of scarcity on social systems and processes, the potential for scarcity engendering grievances, and the degrees to which violence may be aggravated.

Three forms of natural resource scarcity may result from environmental declines, namely: supply-induced scarcity resulting from the degradation and depletion of resources in an environment, demand-induced scarcity arising due to population growth in a given environment or an increase in per capita consumption of a particular resource causing an increase in its demand and structural scarcity which results from inequality in social distribution of a resource concentrating access to relatively few people. These result in resource capture and ecological marginalization (Percival \& Homer-Dixon, 1998). 
The scarcity-conflict nexus is widely acknowledged in policy circles. The former US Secretary of State, John Kerry, pointed out that 'If we don't respond adequately to the challenge of global climate change, over the course of these next years there will be people fighting wars over water and over land' (U.S. Department of State, 2013, n. p.). Similarly, the United Nations' Secretary-General, Ban Ki-Moon, observed that "competition between communities and countries for scarce resources-especially water-was increasing, exacerbating old security dilemmas and creating new ones with advancing desertification and sea level rise, both of which are reshaping the human geography of the planet" (United Nations, 2011, n. p). The importance of these alarms is already evident developing countries where natural resources are known to play critical roles in human migration and settlement (Brown, 2008; Laczko, 2010).

\section{Ecological Vulnerability and Migratory Adaptation}

Human migration runs through many studies on climate change-conflict literature as an important adaptation strategy in poor regions (Bronen et al. 2009; Conley \& Werz, 2012; Hunter \& David, 2011). Although the influence of climate change on human migration is a complex one in need of robust evidence (Bardsley \& Hugo, 2010; Gomez, 2013; Gray \& Bilsborrow, 2013; Piguet, Pécoud, \& de Guchteneire, 2011; Raleigh et al., 2008), human migration is nonetheless widely acknowledged as a common strategy of adaptation when populations are confronted with adverse effects climate change under certain conditions (ACCES, 2010). The role of migratory adaptation as conflict trigger function derives from its implication for access to resources for both migrants and receiving communities (Brown, 2008; IPCC, 2007; Laczko, 2010; Scott, 1995).

Given the consensus that climate change will affect the quality of the environment where livelihoods are dependent on the natural environment, scholars argue that a reduction in the capacity of that environment to sustain human livelihoods will create new forms of displacement as people are likely to move from their original locations in search of livelihood (Black et al 2008; IPCC, 2007; McLeman \& Smit, 2005; Myers, 2002; Raleigh et al, 2008). In this regard, it has been noted that

The destabilising effect of large-scale immigration must be considered in parallel with contextual factors in the receiving area. Conflict may arise when migrants, particularly those of a different nationality or ethnicity, move quickly or in large numbers to areas already suffering from tensions over access to scarce resources and where coping mechanisms are absent (ACCES, 2010, p. 19).

This according to Nordas \& Gleditsch (2007) is because climate change worsens "the challenge of meeting key human needs such as adequate food, clean water, clean air, and adequate and affordable energy services" (p. 529). This linkage is clearly manifest in the Fulani pastoralist experience in Nigeria where increased degradation of the arid climate of the northern region poses increasing threat to the sustainability of pastoral livelihood. 


\section{Arable and Pastoral Agro-cultural Practices in Nigeria}

Nigeria's varied agro-ecological regions and soil types offer varying opportunities for the production of crops and livestock across the country. These regional differentiations in agro-productive traditions come with certain risks in recent times due to increased climatic and ecological pressure. This is more so, with high reliance of the agricultural systems on traditional tools and methods as Nigeria's agricultural production remains mainly at subsistence level (Enete \& Amusa, 2010). As such, the majority of the small scale farmers operate under high exposure to climatic perturbations and uncertainties. Nomadic pastoral farmers in Nigeria have faced increased environmental pressure which affects the patterns of migration and competition for grass and water. As Adekunle \& Adisa (2010) note, conflicts arising from herders' search for resources such as water, forage and land in host communities have remained the "most important" problem faced by Fulani Herdsmen in the course of tending their herds. This has brought about enmity between them and the host community mostly arable crop farmers.

The conflict of agricultural needs among farmers is indicated in the large size of herds and their ubiquity in different parts of the country. Highlighting the significance of pastoral farming in the sub-Saharan Africa region, Majekodunmi, Fajinmi, Dongkum, Shaw and Welburn (2014) noted that there were about 120 million pastoral herdsmen globally. Of this number, about 50 million were to be found in sub-Saharan Africa, representing about $12 \%$ of the population in rural areas. Similarly, Nzeh (2015) noted that the Nigerian livestock production sub-sector accounts for about $25 \%$ of Central and Western Africa's entire livestock holding. There is also substantial cross-border movement in the Fulani livestock rearing trade, although the actual figures in inflow of herds has been difficult to assess. According to Nzeh (2015), Nigeria's cattle market has significant inflow from Niger, Mali, and Chad, with regular cross-border movement of herders and cattle during the yearly migration circles. Nigeria accounts for $50 \%$ of beef consumption in the ECOWAS region and imports over $25 \%$ of this to meet the needs of the rapidly increasing population.

In the Fulani pastoral farming ethnic group, the primary pastoral group numbers about 15.3 million, and are mostly found in the arid and semi-arid northern parts of the country. The lifestyle of the Fulani herders is significantly impacted by climate change in the long-run, and in the short-term, by yearly seasonal changes. Traditionally, the seasonal period of grass scarcity in arid northern regions usually implies more difficult access to feed for the herd during the dry season. This forces the herdsmen into a protective movement to the South which usually has higher wetness and vegetation at such times. Highlighting the pressure for migration caused by changes in the climate of herder communities, Aderinoye-Abdulwahab and Adefalu (2012) explain that "climate change such as desert encroachment makes grazing difficult. As most animal grazing is carried out in drylands, pastoralists and their families are usually affected by harsh 
weather conditions such as droughts which have serious ecological and economic effects on rangelands" (p. 4).

\section{Arable Farming Host versus Migrant Fulani Herders in Nigeria}

The southern region, consisting of the South-West, South-South and the South-East, has witnessed increasing conflict between herders and farmers in recent times. Although this form of conflict is not exclusive to the region, the dominance of arable nature of agriculture in the regions makes it inhospitable to unbridled migration of cattle farmers that are predominant in the northern region. This incompatibility thus provides a clear vista for understanding how environmental declines induce ecological pressures and how this may affect livelihood systems in far-flung areas.

It is noteworthy that the southern region has also not been totally immune to its own forms of exposure to the adverse effects of climatic change. However, this has been compounded by indirect consequences such as rising incidence of violent conflict and general insecurity occasioned by increased drought and desertification and outmigration from the northern region. This is because the southern region receives a larger influx of environmental migrants-migrant pastoralists, thereby forcing two contradictory natural resource user-groups into a tenuous system of cohabitation in the south. Fasona \& Omojola (2005) noted that the effect of prolonged droughts across the northern Sudano-Sahelian region in the 70s, especially for the largely pastoral population, was a wave of ecological migration towards the South which translates to pressure on land and land resources of the Guinea savannah and rainforest zone by the Sahel-Sudan Hausa-Fulani tribe.

The intensification of long range southward migration explains the recurrent communal friction and conflict with the host communities across the southern Guinea savannah and rainforest belt. According to Azuwike \& Enwerem (2010), the increase in the scale of conflict is a result of changes in the nature and frequency of nomadic transhumance in recent decades. Migration over the years, have been planned in tandem with seasonal considerations for planting and harvesting periods, the risk of violence have been minimal. Two patterns of pastoral presence are often noted in studies on pastoral migration and host community relations (see for example: Azuwike \& Enwerem, 2010; Kratli, 2008; Kratli \& Schareika 2010). These include: (a) transitory migration in which herders are a continuous movement of cattle dictated by seasonal characteristics and availability of forage and (b) sedentary movement in which there is either a permanent or semi-permanent relocation of herdsmen. While semi-permanent sedentary relocation often involves identifying an area for all-years-round grazing opportunities and the development of temporary huts until the need to move arises, increasing acclimatization to the environment and the cost of repeated resettlements has made permanent stays increasingly attractive to many herders. 
While the first form of transit movement appears to have increased in intensity, extending into the planting season and thereby constituting a higher risk for the farmers' crops, the latter has increased in size and demand with claims to land and community rights emerging as new challenges to the host communities. More so, herdsmen grazing sojourn beyond the post-harvest season in arable farming areas has meant increased risks to damage crops in the planting season breeding conflicts as a result (Azuwike \& Enwerem, 2010). Concerns also arise in some communities with the trend of pastoralfarmer militancy, as the herders increasingly adopt the practice of bearing sophisticated guns and arms rather than the herding staff, ostensibly for protecting themselves-a practice farmers often claim, was to make their resistance impossible or to overpower whatever resistance arises when Fulani cattle are left to wander into farms causing destruction of crops. Such transformations have altered the traditionally cordial relationship between the migrant and the host.

\section{General Socio-demographic Background of Study Area}

Data was collected in four states, namely: Ekiti, Kwara, Oyo and Nasarawa states. Data collection consisted of 120 key informant interviews with clusters of respondents including farmers, herdsmen, local government administrators, traditional rulers and youths. A spatial observation and socio-statistical overview of communities examined in the study highlighted certain population characteristics.

Ages of farmers across host communities range between 18 to 70 years. Youths are in the majority at about $58 \%$ of the farming population. About $4 \%$ of youths interviewed are employed in the civil or teaching service and most combine agriculture with their employment. About $60 \%$ of the youth combine other jobs, such as commercial motorcycle transport or artisans, with farming while about $25 \%$ are involved only in agriculture. Nasarawa farmers have the lowest level of formal education among the four areas studied: about $75 \%$ of the farmers have no formal education and about $20 \%$ had attained primary school level with $5 \%$ had secondary education in contrast, for example, to Ekiti which has the highest level of formal education among farmers. Most food production activities in all the communities are done at subsistence level with significant presence of team-farming ${ }^{1}$ among the youth.

Most native community youths engaged in the study are male, although it is noted that a substantial number of the females were also involved in farming. According to participants, most females often provide labour in support of the men assisting in planting, harvesting and processing of crops in household farms. Participants in Kwara and Oyo noted that there has been a reduction in the involvement of women and children and, by extension, their supply of labour input into farming due to rising insecurity in their farmsteads. The majority of the youth have formal education with a minimum of a junior secondary school certificate. About $2 \%$ are graduates of tertiary institutions, combin- 
ing farming with civil service employment, and 30\% are at various levels of education. On the other hand, about $10 \%$ of the herders attained education up to primary school certificate level. About 75\% had Arabic education while 15\% had no formal or Arabic education. About $20 \%$ of the herders are aged between 45 to 75 years, while the rest are aged between 12 and 44 years. There is a significant number of women and children in herders' settlements. Most households are large with sizes ranging between 8 and 14 and wives between 2 and 4. Cattle herding activities are taken up by men while the females oversee day to day processing of by-products such as dairy milk and growing of seasonal crops. Settlement history of sedentary herders interviewed range from 5 to 25 years.

\section{Findings}

\section{Climate Change and the Dynamics of Pastoral Migration}

In order to understand linkage(s) between climate change and natural resource contestation in Efon-Alaaye in Ekiti, Iseyin/Shaki in Oyo, Udeni-Gida in Nasarawa, Nasarawa state and Oke-Ero in Kwara, Nigeria, the study probed intervening factors between primary vulnerability among herdsmen and secondary vulnerability in host communities.

\section{Factors Motivating Pastoral Migration}

Findings: Four factors were highlighted by respondents. These include environmental scarcity, environmental variability, population pressure, and other personal contingencies. These are presented in an order of significance. ${ }^{3}$ Although its ramifications are understood in terms of geophysical, seasonal and inter-annual variability experiences, environmental decline and resource scarcity ranked as the most significant factor motivating southward migration among cattle herders (See table). The importance of environmental pressure to migratory decision is captured thus:

We herders are often chased about by drought. It is often said that pastoral farmers have no home. We do have homes, but our profession forces us to move when we are confronted with drought. When we come to a place where the environment is conducive, we desire to stay. Many of us have become comfortable and prefer to stay permanently rather than migrating every now and then. There is a huge difference between here [Efon-Alaaye] and there [northern region]: the cows are feeding well here, and reproduce faster here than in the north where feed is scarce (PH5, Efon Alaaye, May, 2014).

3 Contingency-induced migration refers to those not directly relating to environmental or demographic pressures on each herdsman, for example the need to move because of other family members' migration. 
Pastoral Farmers' Perception of Factors Influencing North-South Migration ${ }^{4}$

\begin{tabular}{clcccccc}
\hline S/N & \multicolumn{1}{c}{ Factors } & EEA $^{2}$ & KOE & OS-I & NAS & $\Sigma$ & $\%$ \\
\hline 1 & Environmental Variability & 3 & -- & -- & 1 & 4 & $15.4 \%$ \\
2 & Environmental Resource Scarcity & 5 & 5 & 5 & 3 & 18 & $69.2 \%$ \\
3 & Population Pressure & 2 & -- & -- & -- & 2 & $7.7 \%$ \\
4 & Contingency Factors & -- & -- & -- & 2 & 2 & $7.7 \%$ \\
& & & & & & 26 & $100 \%$ \\
\hline
\end{tabular}

Source: Authors.

As shown above, factors relating to observed environmental variability and decline in natural resource carrying capacity assessed over time accounted for $69.2 \%$ in herders' motivation reference. As shown in the table above, the impacts of climate change as motivation for migratory adaptation is understood by herdsmen in terms of its effects experienced as inter-annual geo-physical declines in cattle-sensitive environmental resources. In comparison with seasonal change, herders demonstrate a proper grasp of inter-annual patterns in variability and are able to differentiate between seasonal weather changes and longer-term climate change. They are also able to recognize pressures from climatic changes as distinct from pressures arising from demographic increase population and herd holdings.

While respondents acknowledge the importance of demographic factors, majority affirm higher push pressures from increased levels of inter-annual environmental decline evident in prolonged drought and cattle-sensitive resource scarcity prior to migration from previous locations. One respondent puts it thus: "I know that there is scarcity of grass because of longer dry season and increasing drought there [referring to Sokoto State in the northern region]" (NAS PH4, June, 2014). Another herdsman explains that:

At a point, during the dry seasons, streams remain the source of water, but in recent years, the dry season no longer leaves water in the streams. Same also applies to the grasses. That is the reason why we have to move to this area and I decided to settle permanently since I find grass with relative ease throughout the year (EEA PH5, May, 2014).

This indicates that farmers recognize resource scarcity as one of the key consequences of observed inter-annual variability. The distribution of the causal agency in pastoral migration can be graphically summarized thus:

4 Abbreviation show state and local government areas where interviews were conducted and where responses in tables were obtained (EEA= Ekiti: Efon Alaye; KOE= Kwara: Oke-Ero; OSI= Kwara: Oke-Ero; and NAS = Nasarawa state: Nasarawa (Udeni Gida). 
Factors Motivating Pastoral Migration

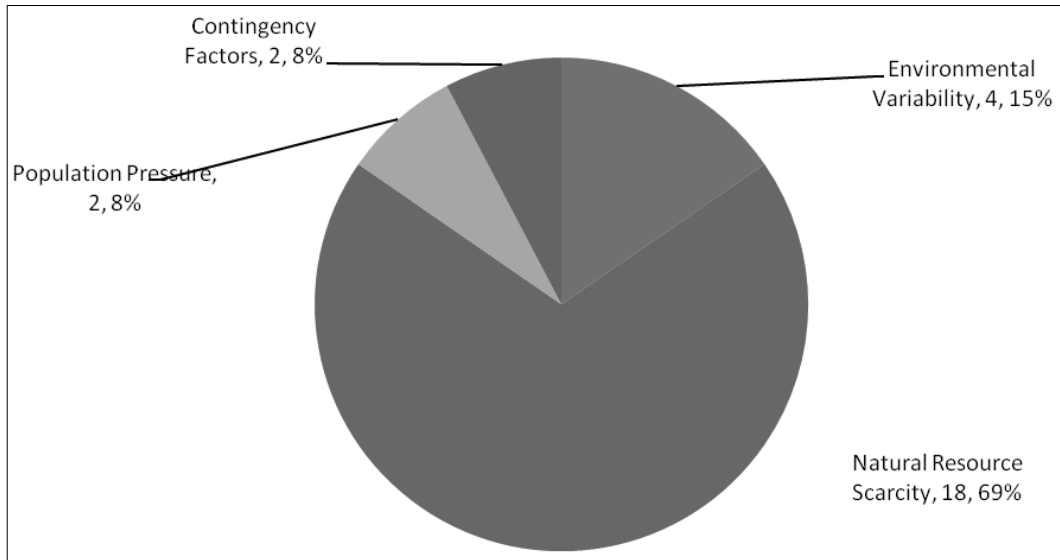

Source: Authors.

\section{Fault-lines in Herder-Farmer Conflict}

We analyze the observed causes of conflict between herdsmen and farmers as reported by herdsmen in order to see whether or not there are similarities in their understanding of tension points. The table also shows most significant causes in farmer-herder relationship in the study area. While $20 \%$ of the herdsmen reported no major conflict with farmers, $15 \%$ reported conflict relating to harassment, theft and assault on women, $65 \%$ reported conflict arising from resources, including encroachment of farms, damage to crops and competition for access to water sources. This shows conformity with theoretical narratives identified in eco-violence theory, as underlying resource competition, deprivation and frustration which results in aggressive behaviour. The table below shows response among herdsmen of underlying causes of conflict with farmers in their host communities.

Herders Perception on Patterns of Farmer-Herder Fault lines

\begin{tabular}{clcccccc}
\hline S/N & \multicolumn{1}{c}{ Factors } & EEA & KOE & OS-I & NAS & $\sum$ & $\%$ \\
\hline 1 & No conflicts & 3 & 1 & 0 & 0 & 4 & $20 \%$ \\
2 & Socio-cultural conflict & 0 & 1 & 1 & -- & 3 & $15 \%$ \\
3 & Resource use conflict & 2 & 3 & 4 & 5 & 13 & $65 \%$ \\
\hline
\end{tabular}

Source: Authors.

From the table above, resource-related contestations was identified as accounting for greater risks of conflict than socio-cultural differences between pastoral farmers and their host community. Fault lines identified relate to tension in the use of critical resources by herdsmen, on one hand, and the protection of those resources on the part of the community. A herdsman puts this rivalry thus: "...they are friendly but you know 
cattle are not humans, and no matter what you do with large herd, they will roam into peoples' farm when there are many farms around. That is where we often have problems" (EEA, PH5, May, 2014).

Both sides identify some factors as specifically underlying grievances. For farmers, factors spurring conflict include encroachment of farmer's fields and destruction of crops by cattle, pollution of community's water sources by cattle, crop theft by herdsmen, alleged civil crimes, including harassment of community members by herdsmen, robbery and rape by herdsmen. On the other hand, herdsmen reported encroachment by farmers into allocated grazing reserves, blockage of access roads to water sources, cattle theft or poisoning. A head of a settlement puts strains in farmer-herder relationship thus:

About the farmers, we have a problem which pertains to our cattle eating the farmers' crops. The other challenge which we also have is theft of our cattle. The natives shoot our cattle and drag them away to eat them. In this regard, I have lost up to 6 of my cows. But we always settle the issues because we also offend them too. Even when there are actual cases of stealing, they isolate the herdsman's involvement. Another problem relates to accusations that our cattle herders rob the community people. People pretend to be herders and then commit armed robbery on the highways so that the community will blame the herdsmen (EEA, PCH, May 2014).

\section{Systemic Factors in Farmer-Herder Conflict Transformation}

This section addresses the importance of socio-contextual and systemic factors including institutional processes, populations' economic circumstances, and adjudicative processes, in conflict transformation among vulnerable groups in the study area. Findings are narrative and presented in tables or graphically where applicable.

\section{Environment-dependency and Resource Contestations}

The patterns of economic activities in the rural communities show that subsisting levels of poverty and the range of opportunities available for survival in a given area significantly affects the chances of natural resource struggle among groups. All host communities studied had largely agriculture-based activities. In the absence of industrial or medium scale besides few elementary and school teachers, local government officials and petty trading kiosks, over 70 percent of adult males are engaged in farming. Almost all adults combine farming activities with other occupations such as teaching, artisans and commercial motorcycle transportation known in local parlance as 'Okada' or 'Ashaba'.

Studies have linked occupational displacement among farmers as one of the reasons for increasing number of commercial motorcycle transporters in rural communities. Some authors specifically link this trend to pastoral invasion. For example, Ofem \& Bassey (2014) noted that the invasion of farmers' crops by Fulani cattle "has not only 
created an impediment on the survival of the host communities, but has for instance led to crop-farmers abandoning farming for lesser occupations like Okada riding and other artisan vocations" (p. 513). The reliance of the population on agriculture heightens the stake in the event of crop damages and couples with the large presence of youths raise the risk of violence.

\section{Conflict Management Systems in Farmer-Herder Violence}

The effectiveness of conflict mediation systems in ensuring just and adequate mediation in conflict situations plays an important role in preventing the escalation of violent conflict among groups. Here we tabulate the conflict response preferences among two aggrieved groups: farmers and native community youths. It is noteworthy that most of the youths are also either currently involved,or recently involved in farming in most communities studied.

Strategies Adopted by Farmers in Addressing Conflicts

\begin{tabular}{cccccccc}
\hline S/N & Approaches & EEA & KOE & OS-I & NAS & $\sum$ & $\%$ \\
\hline 1 & Recourse to Traditional Authority & 5 & 3 & 4 & 3 & 15 & $37.5 \%$ \\
2 & Recourse to State Authority & 1 & 2 & 0 & 1 & 4 & $10 \%$ \\
3 & Recourse to Associational Bodies & 2 & 2 & 2 & 2 & 8 & $20 \%$ \\
4 & Recourse to Self-Defence & 1 & 3 & 4 & 4 & 12 & $30 \%$ \\
5 & None & 1 & 0 & 0 & 0 & 1 & $5 \%$ \\
$\Sigma$ & 10 & 10 & 10 & 10 & & \\
& & & & & 40 & $100 \%$ \\
\hline
\end{tabular}

Source: Authors.

From the table above, a high number of affected farmers (30\%) rely on self-help or selfdefence measures. This is surpassed only by recourse to traditional authority which was preferred by $37.5 \%$ of the farmers. There is no doubt that self-help approaches that are not mediated by neutral and impartial adjudicators open the space to unpredictable outcomes including violence and subsequent counter-attacks. The preference for traditional authorities is apparently due to the perception of relative ownership of the system by the aggrieved farmers hence a higher level of trust regarding its perceived attributes including the sanctity and integrity of traditional adjudication, sensitivity to context, neutrality and effectiveness of traditional conflict mediators, most of whom are also farmers. The influence of traditional authority is significant in that most of the conflicts are settled at the local level and rarely extends to the attention of state administrative authorities except where conflicts have escalated into major violence. Perceived failure to do justice at this level, however, leads to a breakdown of confidence. The popularity of this institution notwithstanding, there is a notable decline in its effectiveness. This, according to Baca (2015) is a consequence of the changing political economy of power in the country. A major effect of this transformation is emergence of formal leadership at the local level. 
When aggregated, the data obtained shows that $67.5 \%$ preferred third party mediation when contestation arose as against $35 \%$ which resorted to self-defence $(30 \%)$ or did nothing (5\%). This shows that institutions both at the traditional and formal levels still play important roles in conflict prevention and management. This institutional mediation factor is also seen in the variations in the propensity to violence in each of the areas examined. For example, farmers in both Ekiti (Efon Alaaye) and Kwara (Oke-Ero) recorded high indicators in the resort to third party mediation with $80 \%$ and $70 \%$ respectively. Correspondingly, both states (Ekiti and Kwara) also recorded low indicators on resort to self-help with $10 \%$ and $30 \%$ respectively. The high score recorded for institutional mediations also raises question about the effectiveness of such interventions as a popular option in conflict mediation among the population. Effectiveness determines the level of community confidence in the mediating institution, as well as the credibility of outcomes. It is the combined effects of these that reduced people's inclination to resort to self-help and violence, thereby preventing the escalation

\section{Conclusion}

This paper examined the connection between climate change and violent conflicts. This linkage is re-visited against the backdrop of controversies surrounding the climate change-conflict discourse. The controversies stem largely from two competing priorities: the need for development of a universally valid theory on the climate change-conflict discourse, on one hand, and the need for development of appropriate policy response in specific contexts of vulnerability, on the other. In view of the important role socioeconomic and political contexts play in the climate change-conflict transformation process (Wolf, 2011), we contextualized the linkage by examining the contribution of climate change to the growing incidence of farmer-herder conflict in Nigeria.

Viewed from a Relative Deprivation theoretical prism, the study identified natural resource scarcity, migratory adaptation and resource struggle in host communities as important causal trajectories in conflict transformation. From the study, it is evident that under certain conditions, the demographic and ecological pressures resulting from climate change aggravates livelihood constrictions and struggles among individuals and groups that may escalate into violence or lead to the escalation of existing conflicts.

As shown in the data analysis presented, climate change ranks as the most significant factor accounting for changing patterns of pastoral migration in Nigeria. Given the predominance of arable farming in the southern region, the combined effects of exposure to climate-induced declines in natural resources relied upon by herders in the arid and semi-arid regions especially in the North, often give rise to migratory adaptation which in turn leads to competition over access to, and control of these resources in host communities. The conflict trigger effect of cattle encroachment and destruction of farmers' crops on one hand, or cattle theft and related losses among herders on the other hand, 
results in a frustration-aggression scenario among both groups which account for the rising incidence of violent conflict in recent times. We conclude, therefore, that climate change is a remote causal factor in violent conflict between farmers and herders over natural resources in Nigeria. The paper submits that future exploration of the climate change-conflict linkage need to be situated within specific socio-cultural, economic and political context in order to yield policy-relevant findings. As the Nigerian case shows, the nature of the social, economic, cultural and political contexts play a defining role in attenuating or aggravating conflict transformation, hence the need for the Nigerian state to contextualise its climate change impact assessment and adaptation intervention strategies.

\section{References}

1. Abbass, I. M. (2011). No Retreat, No Surrender: Conflict for Survival between Fulani Pastoralist and Farmers in Northern Nigeria. European Scientific Journal, 8(1), 153-166.

2. ACCES. (2010). Climate Change and Security in Africa: Vulnerability Report. The Africa, Climate Change, Environment and Security (ACCES) Dialogue Forum, Event Report 11, UN Conference Centre, Addis Ababa, Ethiopia.

3. Adano, W. R., Dietz, T., Witsenburg, K., \& Zaal, F. (2012). Climate Change, Violent Conflict and Local Institutions in Kenya's Drylands. Journal of Peace Research, 49, 65-80.

4. Adekunle, O. A., \& Adisa, S. R. (2010). An Empirical Phenomenological Psychological Study of Farmer-Herder Conflicts in North-central Nigeria. Journal of Alternative Perspectives in the Social Sciences, 2(1), 1-27.

5. Aderinoye-Abdulwahab, S. A., \& Adefalu, L. L. (2012, February 7-10). Pastoral Communities in Nigeria: Another Case of Marginalisation. 56th Australian Agricultural and Resource Economics Society (AARES) Annual Conference, Fremantle, Western Australia.

6. Amobi, D. \& Onyisi, T. (2015). Governance and Climate Change in Nigeria: A Public Policy Perspective. Journal of Policy and Development Studies, 9(2), 199-209.

7. Anderson, C., Anderson, K., Dorr, N., DeNeve, K., \& Flanagan, M. (2000). Temperature and aggression. Advances in experimental social psychology, 32, 63-133.

8. Anderson, C. A., \& DeLisi, M. (2011). Implications of Global Climate Change for Violence Developed and Developing Countries. In J. Forgas, A. Kruglanski and K. Williams (Eds), The Psychology of Social Conflict and Aggression (pp. 249-266). New York: Psychology Press.

9. Azuwike 0. D., \& Enwerem, E. (2010). Nigeria's Changing Environment and Pastoral Nomadism: Redistribution of Pains and Gains. Owerri: Imo State University.

10. Baca, M. W. (2015). Farmer-Herder Clashes Amplify Challenge for Beleaguered Nigerian Security. IPI Global Observatory. Retrieved from http://theglobalobservatory. org/2015/07/farmer-herder-nigeria-buhari-abuja-fulani/.

11. Baechler, G. (1998). Why Environmental Transformation Causes Violence: A Synthesis, Env. Change and Security Project Report, 4, 24-44. 
12. Baechler, G. (1999). Environmental Degradation and Violent Conflicts: Hypothesis, Research Agendas and Theory-building. In M. Suliman (Ed.), Ecology, Politics and Violent Conflicts (pp. 76-112). New York: Zed Books.

13. Bardsley, D. K., \& Hugo, G. J. (2010). Migration and Climate Change: Examining Thresholds of Change to Guide Effective Adaptation Decision-making. Population and Environment, 32(2-3), 238-262.

14. Barnett, J. (2003). Security and Climate Change. Global Environmental Change, 13, 7-17

15. Barnett, J., \& Adger, W. N. (2007). Climate Change, Human Security and Violent Conflict. Political Geography, 26, 639-655.

16. Bauhaug, H. (2010). Climate not to blame for African civil wars, PNAS, 107(38), 16477 16482.

17. Bauhaug, A., Gleditsch, N. P., \& Theisen, O. M. (2008, March 5-6). Implications of Climate Change for Armed Conflict. Paper presented at the World Bank Workshop on Social Dimensions of Climate Change. The World Bank, Washington DC.

18. Black, R., Kniveton, D., Skeldon, R., Coppard, D., Murata, A., \& Schmidt-Verkerk, K. (2008). Demographics and Climate Change: Future Trends and their Policy Implications for Migration, Working Paper T-27. London: DFID.

19. Bronen, R., Chandrasekhar, D., Conde, D. A., Kavanova, K., Moriniere, L., Schmidt-Verkerk, K., \& Witter, R. (2009). Stay in Place or Migrate: A Research Perspective on Understanding Adaptation to a Changing Environment. In A. Oliver-Smith and X. Shen (Eds.), Linking Environmental Change, Migration and Social Vulnerability (pp. 12-21). Bonn, Germany: UNU Institute for Environment and Human Security (UNU-EHS).

20. Brown, 0. (2008). "The Number Game: Climate Change and Displacement", Forced Migration Review, 31. Oxford: Refugee Studies Centre.

21. Buseth, J. T. (2009). Conflicting Livelihoods and Resources in the Time of Global Warming: the Political Ecology of Farmer-Herder Conflict in Mopti, Mali. Noragic: Department of International Environment Studies, Norway.

22. Coetzee, W. S. (2012). The role of Environment in Conflict: Complex Realities in PostCivil War Nigeria. Stellenbosch: Stellenbosch University.

23. Conley, L., \& Werz, M. (2012). Climate Change, Migration, and Conflict: Addressing Complex Crisis Scenarios in the 21st Century. ISSUELAB. Retrieved from www.issuelab. org/permalink/resource/12216.

24. Conley, L. (2011). United Nations Misses Broader Climate Change Connection, Issues in National security. Centre for American Progress. Retrieved from www.americanpro gress.org/issues/security/news/2011/07/22/9928/united.nat.

25. Cook, T. D., Tang, Y., \& Seidman, D. S. (2014). Causally Valid Relationships That Invoke the Wrong Causal Agent: Construct Validity of the Cause in Policy Research. Journal of the Society for Social Work and Research, 5, 379-414.

26. Davis J. A. (1959). A formal interpretation of the theory of relative deprivation. Sociometry, 22, 280-296. 
27. Downing, T. E., \& Patwardhan, A. (2003). Vulnerability Assessment for Climate Adaptation. UNDP Adaptation Policy Framework Technical Paper 3. New York: UNDP.

28. Enete, A. A., \& Amusa, T. A. (2010). Contribution of Men and Women to Farming Decisions in Cocoa Based Agroforestry Households of Ekiti State, Nigeria. Tropicultura, 28, 77-83.

29. Fasona, M. J., \& Omojola, A. S. (2005, June 21-23). Climate Change, Human Security and Communal Clashes in Nigeria. Human Security and Climate Change, International Workshop at Holmer Fjord Hotel, Asker, Norway.

30. Flynn, S. I. (2011). Relative Deprivation Theory. Sociology Reference Guide. (pp. 100110). Pasadena: Salem Press.

31. Gartzke, E. (2011, November 15). Blame it on the weather: Seasonality in interstate conflict. Working Paper. San Diego: University of California.

32. Gleditsch, N. P., \& Urdal, H. (2002). Ecoviolence? Links between Population Growth, Environmental Scarcity and Violent Conflict in Thomas Homer-Dixon's Work. Journal of International Affairs, 56(1), 283-302.

33. Gleditsch N. P. (2011). Regional conflict and climate change. Paper presented at workshop on Climate Change Impacts and Associated Economic Damages, Washington DC.

34. Gomez, 0. (2013). Climate change and migration: A Review of the Literature. A study commissioned by the International Institute of Social Studies, The Hague (Erasmus University Rotterdam), International Development Research Centre (Canada).

35. Gray, C., \& Bilsborrow, R. (2013). Environmental Influences on Human Migration in Rural Ecuador, Demography, 1-25.

36. Guimond, S., \& Dube-Simard, L. (1983). Relative deprivation theory and the Quebec nationalist movement: The cognition-emotion distinction and the personal-group deprivation issue. Journal of Personality and Social Psychology, 44, 526-535.

37. Gurr, T. R. (1968). Psychological Factors in Civil Violence. World Politics, 20, 245-278.

38. Gurr, T. R. (1970). Why Men Rebel. Princeton: Princeton University Press.

39. Homer-Dixon, T., \& Blitt, J. (1998). Ecoviolence: Links among Environment, Population, and Security. Lanham: Rowman \& Littlefield.

40. Hunter, L. M., \& David, E. (2011). Displacement, Climate Change and Gender. In E. Piguet, A. Pecoud and P. de Guchteneire (Eds.) Migration and Climate Change (pp. 306330). Cambridge: United Nations Educational, Scientific and Cultural Organization (UNESCO) and Cambridge University Press.

41. Ide, T. (2015). Why do conflicts over scarce renewable resources turn violent? A Qualitative Comparative Analysis. Global Environmental Change, 33, 61-70.

42. IPCC (2007). Climate change 2007: Impacts, Adaptation and Vulnerability. Working Group II contribution to the Fourth Assessment Report of the IPCC Intergovernmental Panel on Climate Change. Geneva: IPCC Secretariat.

43. Joiner, E., Kennedo, D., \& Sampson, J. (2012). Vulnerability to Climate Change in West Africa: Adaptive Capacity in the Regional Context". Student Working Paper N0 4. Climate Change and African Political Stability (CCAPS) Program. Austin: Strauss Center. 
44. Kelly, P. M., \& Adger, W. N. (2000). Theory and Practice in Assessing Vulnerability to Climate Change and Facilitating Adaptation. Climatic Change, 47(4), 325-352.

45. Koubi, V., Spilker, G., Bo“ hmelt, T., \& Bernauer, T. (2014). Do Natural Resources matter for Interstate or Intrastate Armed Conflict? Journal of Peace Research, 51, 227-243.

46. Kratli, S. (2008). Cattle breeding, complexity and mobility in a structurally unpredictable environment: the WoDaaBe herders of Niger. Nomadic Peoples, 12(1), 11-41.

47. Kratli S., \& Schareika N. (2010). Living off uncertainty: The intelligent animal production of dryland pastoralists. European Journal of Development Research, 22(5), 605-622.

48. Laczko, F. (2010). Migration, the Environment and Climate Change: Assessing the Evidence. Study Team on Climate induced Migration. Washington DC: The German Marshall Fund of the United States.

49. Leary, N., \& Kulkarni, J. (2007). Climate Change Vulnerability and Adaptation in Developing Country Regions. Draft Final Report of the AIACC Project, A Global Environment Facility Enabling Activity in the Climate Change Focal Area, Project No. GFL-2328-2724.

50. Liverman, D. M., \& Merideth, R. (2002). Climate and society in the US South west: the context for a regional assessment. Climate Research, 21, 199-218.

51. Majekodunmi, A., Fajinmi, A., Dongkum, C., Shaw, A. P. M., \& Welburn, S. (2014). Pastoral livelihoods of the Fulani on the Jos Plateau of Nigeria. Pastoralism: Research, Policy and Practice, 4(20), 1-16.

52. McLeman R. A., \& Smith, B. (2006). Migration as an Adaptation to Climate Change. Climatic Change, 76(1-2), 31-53.

53. Mearns, R., \& Norton, A. (2010). Social Dimensions of Climate Change. Washington D.C: The World Bank, 47-74.

54. Myers, N. (2002). Environmental refugees: a growing phenomenon of the 21st century. Philosophical Transactions of the Royal Society of London Series B, Biological Sciences, 357(1420), 609-613.

55. Ngigi, S. N. (2009). Climate Change Adaptation Strategies: Water Resources Management Options for Smallholder Farming Systems in Sub-Saharan Africa. New York: The MDG Centre for East and Southern Africa of the Earth Institute at Columbia University.

56. Nordas, R., \& Gleditsch, N. P. (2007). Climate change and conflict. Political Geography, 26(6), 627-638.

57. Nzeh, E. (2015). The Effects of Migration by Nomadic Farmers in the Livelihoods of Rural Crop Farmers in Enugu State, Nigeria. Global Journal of Science Frontier Research: D Agriculture and Veterinary, 15(3), 20-28.

58. Oberschall, A. (1978). Theories of Social Conflict. Annual Review of Sociology, 4, 291315.

59. Ofem, 0. 0., \& Bassey, I. (2014). Livelihood and Conflict Dimension among Crop Farmers and Fulani Herdsmen in Yakurr Region of Cross River State. Mediterranean Journal of Social Sciences, 5(8), 512-519.

60. Olaniyan, A. O., Francis, M., \& Okeke-Uzodike, U. (2015). The cattle are Ghanaians but the herders are strangers: Farmer-herder conflicts, expulsion policy and pastoralist question in Agogo, Ghana. African Studies Quarterly, 15(2), 53-67. 
61. Percival, V., \& Homer-Dixon, T. (1998). Environmental Scarcity and Violent Conflict: The Case of South Africa. Journal of Peace Research, 35, 279-298.

62. Piguet, E., Pécoud, A., \& de Guchteneire, P. (2011). Migration and Climate Change: An Overview. Refugee Survey Quarterly, 30(3), 1-23.

63. Raleigh, C., Jordan, L., \& Salehyan, I. (2008). Assessing the impact of climate change on migration and conflict. World Bank Seminar on Exploring the Social Dimensions of Climate Change. Washington D.C.: The World Bank.

64. Rose, K. A. (2010). Tribal Climate Change Adaptation Options: A Review of The Scientific Literature. Washington: U.S. Environmental Protection Agency, Region 10.

65. Scientific American. (2008). The Physical Science behind Climate Change. Scientific American. Retrieved from www.scientificamerican.com/article/science-behind-cli mate-change/.

66. Scott, M. J. (1995). Human Settlement in a Changing Climate: Impacts and Adaptation. Second Assessment Report of the Intergovernmental Panel on Climate Change (IPCC). Geneva: IPCC Secretariat.

67. Stern, N. (2007). The Economics of Climate Change: The Stern Review. Cambridge: Cambridge University Press.

68. Stojanov, R., Kelman, I., Shen, S., Duží, B., Upadhyay, H., Vikhrov, D., Lingaraj, G.J., \& Mishra, A. (2014). Contextualising Typologies of Environmentally Induced Population Movement. Disaster Prevention and Management: An International Journal, 23(5), 508523.

69. Tir, J., \& Diehl, P. (1998). Demographic pressure and interstate conflict: linking population growth and density to militarized disputes and wars, 1930-89. Journal of Peace Research, 35(3), 319-339.

70. Tompkins, E. L., \& Adger, W. N. (2004). Does Adaptive Management of Natural Resources Enhance Resilience to Climate Change?. Ecology and Society, 9(2), 10.

71. United Nations. (2011). Security Council Meetings Coverage. Security Council 6587th Meeting, 20th July 2011. Retrieved from www.un.org/press/en/2011/sc10332.doc. htm.

72. U.S. Department of State. (2013). Secretary Kerry holds a Google+ hangout with NBC's Andrea Mitchell. U.S. Department of State. Retrieved from www.state.gov/secretary/ remarks/2013/05/209273.htm.

73. Wolf, L. (2011). Climate Change Adaptation as a Social Process. In J. D. Ford and L. Berrang-Ford (Eds.), Climate Change Adaptation in Developed Nations: From Theory to Practice (pp. 21-32). Advances in Global Change Research, 42.

74. Wolt, K. (2011). Climate Change, Environmental Scarcity, and Violent Conflict: Examining Primers and Analyses. Washington: The Evergreen State College. 